BAREKENG: Jurnal Ilmu Matematika dan Terapan

March $2021 \quad$ Vol. 15 No. 1 Page 001-008

P-ISSN: 1978-7227 E-ISSN: 2615-3017

doi : https://doi.org/10.30598/barekengvol15iss1pp001-008

\title{
ANALISIS REGRESI LOGISTIK BINER UNTUK MENENTUKAN FAKTOR STILLBIRTH DI KABUPATEN ACEH TIMUR
}

\section{Analysis of Binary Logistic Regression to Determine Stillbirth Factors in East Aceh District}

\author{
Fitra Muliani $^{1 *}$, Amelia $^{2}$, Ulya Nabilla ${ }^{3}$, Azizah $^{4}$ \\ 1,2,3 Prodi Matematika, Fakultas Teknik, Universitas Samudra \\ Jln. Prof. Syarrief Thayeb, Meurandeh, Langsa, 24416, Indonesia \\ ${ }^{4}$ Prodi Matematika, Fakultas MIPA, Universitas Negeri Malang \\ Jln. Semarang, No. 5, Kota Malang, Jawa Timur, Indonesia
}

Corresponding author e-mail: 1*fitramuliani@unsam.ac.id

\begin{abstract}
Abstrak
Stillbirth merupakan kelahiran bayi dalam keadaan tidak bernyawa yang telah mencapai umur kehamilan 20 minggu atau sebelum masa persalinan. Terdapat beberapa penyebab stillbirth yaitu infeksi selama kehamilan, kelainan atau cacat bawaan, kondisi kesehatan ibu, usia ibu, dan sebagainya. Adapun tujuan penelitian ini untuk meninjau faktor penyebab yang berpengaruh signifikan terhadap stillbirth. Data yang dianalisis merupakan data sekunder yang diperoleh dari Puskesmas Idi Rayeuk dan Dinas Kesehatan Kabupaten Aceh Timur. Data tersebut dianalisis menggunakan regresi logistik biner. Hasil penelitian ditemukan suatu model yang menggambarkan hubungan antara stillbirth pada ibu hamil dengan infeksi kehamilan, cacat bawaan, kondisi kesehatan ibu, dan usia ibu. Berdasarkan model tersebut dapat disimpulkan bahwa, ibu yang mengalami infeksi kehamilan lebih berpengaruh terhadap stillbirth dibandingkan dengan faktor lainnya.
\end{abstract}

Kata Kunci : Stillbirth, Regresi logistik biner, Maksimum Likelihood, Kabupaten Aceh Timur.

\begin{abstract}
Stillbirth is a fetal death that the baby does not have any signs of life after birth and has been passed over 20 weeks and before birth. There are several causes of the stillbirth, they are; the infection during pregnancy, the congenital defects, the mother's condition, the mother's age, etc. The purpose of this research was to review the most significant causative factors on stillbirth. The data that will be analyzed are the secondary data which obtained from Puskesmas Idi Rayeuk and Dinas Kesehatan Kabupaten Aceh Timur. The data will be analyzed by using binary logistic regression analysis. Based on the research, it is discovered a model that describes the relationship between stillbirth in pregnant women with pregnancy infections, congenital defects, maternal health conditions, and maternal age. Based on the model, it stated the mother who has the pregnancy infection has the big impact on stillbirth than the other factors.
\end{abstract}

Keywords: Stillbirth, Logistic binary regression, Likelihood maximum, Kabupaten Aceh Timur.

Article info:

Submitted: $22^{\text {nd }}$ July 2020 Accepted: $13^{\text {th }}$ February 2021

How to cite this article:

F. Muliani, Amelia, U. Nabilla, Azizah, "ANALISIS REGRESI LOGISTIK BINER UNTUK MENENTUKAN FAKTOR STILLBIRTH DI KABUPATEN ACEH TIMUR”, BAREKENG: J. Il. Mat. \& Ter., vol. 15, no. 1, pp. 001-008, Mar. 2021.

This work is licensed under a Creative Commons Attribution-ShareAlike 4.0 International License.

Copyright @ 2021 Fitra Muliani, Amelia, Ulya Nabilla, Azizah 


\section{PENDAHULUAN}

Stillbirth merupakan kelahiran bayi dalam keadaan tidak bernyawa yang telah mencapai umur kehamilan 20 minggu atau sebelum masa persalinan. Kelahiran mati (stillbirth) adalah peristiwa atau kondisi yang terjadi sebelum ekspulsi lengkap atau ekstraksi yaitu bayi mengalami kematian, tanpa ada tanda kehidupan [1]. Pada 2016, hasil riset Badan Pusat Statistik (BPS) mencatat bahwa Angka Kematian Bayi $(\mathrm{AKB})$ di Indonesia mencapai 25,5. AKB adalah angka yang menunjukkan banyaknya kematian bayi usia 0 tahun dari setiap 1000 kelahiran hidup pada tahun tertentu atau dapat dikatakan juga sebagai probabilitas bayi meninggal sebelum mencapai usia satu tahun (dinyatakan dengan per seribu kelahiran hidup)[2]. Dalam hal ini, nilai AKB diperoleh sebesar 25,5 yang artinya ada sekitar 25,5 kematian setiap 1.000 bayi yang lahir [3]. Sementara itu, beberapa penyebab stillbirth yaitu: cacat lahir; masalah tali pusar; masalah plasenta; kondisi ibu seperti diabetes atau tekanan darah tinggi; pembatasan pertumbuhan intrauterine atau IUGR; sangat kurang nutrisi; infeksi selama masa kehamilan; paparan terhadap agen lingkungan seperti pestisida atau karbon monoksida; riwayat pribadi atau keluarga terkait kondisi pembekuan darah seperti trombosis, tromboflebitis, atau emboli paru [4].

Pada Kabupaten Aceh Timur terdapat tiga daerah yang memiliki kejadian stillbirth terbanyak, yaitu Idi Rayeuk, Darul Aman, dan Peureulak Kota. Berdasarkan data yang diperoleh dari dinas kesehatan Kabupaten aceh Timur dan Puskesmas Idi Rayeuk terdapat 55 kejadian stillbirth tahun 2017 pada tiga daerah tersebut. Dinas kesehatan Aceh Timur mengungkapkan bahwa faktor penyebab kejadian stillbirth, yaitu infeksi selama kehamilan, kelainan atau cacat bawaan, kondisi kesehatan ibu dan usia ibu.

Hasil penelitian yang dilakukan oleh [5] menyatakan bahwa faktor risiko terjadinya stillbirth adalah usia 20-35 tahun, paritas multipara dan penyulit kehamilan seperti preeklampsia. Sedangkan penelitian [6] menyatakan variabel yang berhubungan dengan kejadian lahir mati adalah riwayat penyakit, pemeriksaan antenatal care, dan ketuban pecah dini. Kedua penelitian tersebut dikaji secara deskriptif. Oleh karena itu, peneliti melakukan analisis faktor - faktor stillbirth menggunakan regresi logistik biner untuk mengkaji lebih dalam faktor yang berpengaruh secara signifikan terhadap stillbirth [7]. Regresi logistik adalah sebuah pendekatan untuk membuat model prediksi [8]. Menurut [9], metode regresi logistik biner tersebut merupakan suatu metode analisis data yang untuk mencari hubungan antara variabel respon $(y)$ yang bersifat biner dengan variabel prediktor $(x)$. Nilai variabel $\mathrm{Y}=1$ menyatakan adanya suatu karakteristik dan $\mathrm{Y}=0$ menyatakan tidak adanya suatu karakteristik [10]. Fungsi dari model tersebut berbentuk S-Shape yang mendeskripsikan gabungan beberapa variabel prediktor yang berpengaruh terhadap variabel respon [11].

Rumusan masalah dalam penelitian ini adalah bagaimana penerapan model regresi logistik biner untuk mengetahui faktor-faktor secara signifikan terhadap stillbirth di Kabupaten Aceh Timur. Data dalam penelitian ini merupakan data ibu hamil dan data ibu hamil yang mengalami stillbirth di Kabupaten aceh Timur. Metode yang digunakan untuk menaksir parameter model adalah metode maksimum likelihood. Tujuan dari penelitian ini adalah untuk mengetahui faktor apa saja yang berpengaruh terhadap stillbirth di Kabupaten Aceh Timur.

\section{METODE PENELITIAN}

Penelitian ini menggunakan metode pengamatan data sekunder yang diperoleh dari Dinas Kesehatan Kabupaten Aceh Timur dan Pukesmas Idi Rayeuk. Adapun jenis data yang digunakan yaitu data rekapitulasi jumlah ibu hamil di Dinas Kesehatan Kabupaten Aceh Timur dan data rekapitulasi jumlah ibu yang mengalami stillbirth Tahun 2017. Tahapan-tahapan yang dilakukan dalam menganalisis data pada penelitian ini adalah:

1) Menyusun data berdasarkan faktor penyebab stillbirth;

Variabel respon memiliki dua kategori yang digunakan seperti pada Tabel 1:

Tabel 1. Variabel Respon

\begin{tabular}{ccc}
\hline No. & Variabel Respon & Keterangan \\
\hline 1 & $Y=0$ & bayi yang tidak mengalami stillbirth \\
\hline 2 & $Y=1$ & bayi yang mengalami stillbirth \\
\hline
\end{tabular}


Variabel prediktor yang digunakan didasarkan pada faktor-faktor penyebab kejadian stillbirth pada bayi. Adapun beberapa kategori pada variabel prediktor dapat dilihat pada Tabel 2, berikut ini:

Tabel 2. Variabel prediktor

\begin{tabular}{ccl}
\hline No. & Variabel Prediktor & \multicolumn{1}{c}{ Keterangan } \\
\hline 1 & $X_{1}$ & Infeksi selama Kehamilan \\
\hline 2 & $X_{2}$ & Kelainan atau Cacat Bawaan \\
\hline 3 & $X_{3}$ & Kondisi Kesehatan Ibu \\
\hline 4 & $X_{4}$ & Usia Ibu \\
\hline
\end{tabular}

2) Melakukan analisis data dengan menggunakan statistik deskriptif;

Statistik deskriptif menguraikan atau memberikan keterangan-keterangan mengenai suatu data atau keadaan atau fenomena [12].

3) Melakukan penaksiran parameter

Dalam regresi logistik, variabel $y_{i}, i=1, \ldots, n$ mengikuti fungsi probabilitas Bernuolli yang memiliki nilai 1 dengan probabilitasnya $\pi_{i}$ dan 0 dengan probabilitasnya $1-\pi_{i}$ [13]. Penduga parameter dalam regresi logistik dilakukan dengan cara metode maksimum likelihood[14]. Menurut Hosmer [15], fungsi likelihood distribusi Bernoulli untuk $n$ sampel independen adalah

$l(\beta)=\prod_{i=1}^{n} p\left(x_{i}\right)^{y_{i}}\left(1-p\left(x_{i}\right)\right)^{1-y_{i}}$

dan log-likelihood atau logaritma natural fungsi probabilitas bersamanya adalah

$L(\beta)=\ln l(\beta)$

$=\ln \prod_{i=1}^{n} p\left(x_{i}\right)^{y_{i}}\left(1-p\left(x_{i}\right)\right)^{1-y_{i}}$

$=\sum_{i=1}^{n} y_{i}\left(\beta_{0}+\beta_{1} x_{i}\right)-\sum_{i=1}^{n} \ln \left(1+\exp \left(\beta_{0}+\beta_{1} x_{i}\right)\right)$

Taksiran parameter $\beta_{k}, k=0,1, \ldots, p$ diperoleh dengan mendiferensialkan fungsi log-likelihood terhadap $\beta_{k}$. Nilai maksimum diperoleh menggunakan metode iterasi jika hasil diferensial fungsi log-likelihood bernilai nol.

4) Melakukan uji signifikansi parameter secara serentak dan parsial untuk semua variabel prediktor

a. Uji signifikansi parameter model secara bersama

Pembentukan model regresi logistik serentak bertujuan untuk memperoleh model yang tepat dan sederhana berdasarkan faktor-faktor yang dianggap berpengaruh terhadap variabel respon[16]. Selain itu uji ini dilakukan untuk mengetahui signifikansi parameter $\beta_{k}$ terhadap variabel respon secara keseluruhan. Pengujian tersebut menggunakan statistik uji $G$ yang mengikuti distribusi Chi-Square. Uji Chi-Square merupakan uji statistik non-parametrik yang membandingkan dua kelompok atau lebih pada data-data yang telah dikategorisasikan [17]. Berikut ini statistik uji $G$ yang digunakan

$$
G=-2 \ln \frac{\left(\frac{n_{1}}{n}\right)^{n_{i}}\left(\frac{n_{0}}{n}\right)^{n_{0}}}{\sum_{i=1}^{n} \widehat{\pi}_{l}^{y_{i}}\left(1-\widehat{\pi}_{l}\right)^{\left(1-y_{i}\right)}}
$$

dengan daerah penolakannya $G>X^{2}(v, \alpha)$. Sedangkan hipotesisnya adalah

$H_{0}: \beta_{0}=\beta_{1}=\cdots=\beta_{p}=0$

$H_{1}$ : paling sedikit ada satu $\beta_{k} \neq 0$, dengan $k=0,1, \ldots, p$

b. Uji signifikansi parameter model secara terpisah

Hasil pengujian secara individual akan menunjukkan suatu variabel prediktor layak pada suatu model. Uji signifikansi parameter model secara terpisah ini menggunakan statistik uji Wald seperti di bawah ini.

$W=\frac{\widehat{\beta}_{j}}{S E\left(\widehat{\beta}_{j}\right)}$

Sedangkan hipotesis yang digunakan adalah

$H_{0}: \beta_{k}=0$

$H_{1}: \beta_{k} \neq 0$, dengan $k=0,1, \ldots, p$

Dengan daerah penolakannya $|W|>Z_{\alpha / 2}$.

Uji Wald bertujuan untuk mengetahui peranan masing-masing prediktor terhadap variabel respon[18]. 
5) Melakukan pemilihan model terbaik

Model terbaik dibentuk berdasarkan atas variabel prediktor yang berpengaruh secara signifikan terhadap variabel respon. Oleh karena itu, variabel yang tidak berpengaruh secara signifikan tidak digunakan pada model.

6) Melakukan uji kecocokan model

Uji kecocokan model yang digunakan pada penelitian ini adalah uji Hosmer dan Lemeshow. Statistik uji Hosmer dan Lemeshow $\hat{C}$ yang dihitung berdasarkan nilai $y=1$ dirumuskan sebagai berikut.

$$
\hat{C}=\sum_{r=1}^{g} \frac{\left(o_{r}-n_{r} \overline{p_{1 r}}\right)^{2}}{n_{r} \bar{p}_{1 r}\left(1-\overline{p_{1 r}}\right)}
$$

dengan $\overline{p_{1 r}}$ menyatakan rata-rata taksiran probabilitas sukses kelompok ke-r, $O_{r}$ adalah jumlah sampel kejadian sukses dalam kelompok ke- $r, n_{r}^{\prime}$ adalah total sampel kelompok ke- $r$, dan $\sum_{r=1}^{g} n_{r}^{\prime}=n$, dengan $r=1,2, \ldots, g$. Statistik uji $\hat{C}$ mendekati distribusi Chi-Square dengan derajat bebas $g-2$ [15]. Hipotesis nol menyatakan bahwa model cocok dengan data. Hipotesis nol ditolak jika $\hat{C}>X^{2}(\alpha, g-2)$.

7) Interpretasi parameter logistik dan kesimpulan.

\section{HASIL DAN PEMBAHASAN}

Data yang dianalisis merupakan data sekunder yang diperoleh dari Dinas Kesehatan Kabupaten Aceh Timur. Data yang digunakan merupakan data ibu yang hamil diasumsikan mengikuti regresi logistik biner berserta faktor yang diduga berpengaruh terhadap stillbirth pada ibu hamil di Aceh Timur pada Tahun 2017. Data yang akan dilakukan dalam penelitian ini dapat dilihat pada Tabel 3, berikut:

Tabel 3. Data Penelitian

\begin{tabular}{cccccc}
\hline No & $\mathbf{Y}$ & $\mathbf{X}_{\mathbf{1}}$ & $\mathbf{X}_{\mathbf{2}}$ & $\mathbf{X}_{\mathbf{3}}$ & $\mathbf{X}_{\mathbf{4}}$ \\
\hline 1 & 1 & 1 & 0 & 0 & 33 \\
\hline 2 & 1 & 1 & 0 & 0 & 38 \\
\hline 3 & 0 & 1 & 0 & 1 & 31 \\
\hline 4 & 0 & 0 & 1 & 0 & 32 \\
\hline 5 & 0 & 1 & 0 & 0 & 24 \\
\hline 6 & 0 & 0 & 1 & 0 & 24 \\
\hline 7 & 0 & 0 & 0 & 0 & 26 \\
\hline 8 & 1 & 1 & 0 & 1 & 36 \\
\hline 9 & 1 & 0 & 1 & 0 & 30 \\
\hline 10 & 1 & 1 & 0 & 0 & 25 \\
\hline 11 & 0 & 1 & 0 & 1 & 40 \\
\hline 12 & 0 & 0 & 0 & 0 & 31 \\
\hline 13 & 1 & 0 & 1 & 0 & 39 \\
\hline 14 & 1 & 1 & 0 & 1 & 25 \\
\hline 15 & 1 & 1 & 0 & 0 & 26 \\
\hline 16 & 0 & 0 & 1 & 0 & 38 \\
\hline 17 & 1 & 1 & 0 & 1 & 31 \\
\hline 18 & 0 & 0 & 0 & 0 & 37 \\
\hline 19 & 0 & 1 & 0 & 0 & 37 \\
\hline 20 & 0 & 0 & 1 & 0 & 36 \\
\hline 21 & 1 & 0 & 1 & 0 & 40 \\
\hline & & & &
\end{tabular}

\begin{tabular}{llllll}
\hline No & $\mathbf{Y}$ & $\mathbf{X}_{\mathbf{1}}$ & $\mathbf{X}_{\mathbf{2}}$ & $\mathbf{X}_{\mathbf{3}}$ & $\mathbf{X}_{\mathbf{4}}$ \\
\hline 22 & 1 & 1 & 0 & 0 & 30 \\
\hline 23 & 0 & 0 & 1 & 0 & 26 \\
\hline 24 & 0 & 0 & 1 & 0 & 39 \\
\hline 25 & 1 & 1 & 0 & 1 & 31 \\
\hline 26 & 1 & 1 & 0 & 0 & 24 \\
\hline 27 & 1 & 0 & 1 & 0 & 40 \\
\hline 28 & 1 & 1 & 0 & 1 & 30 \\
\hline 29 & 0 & 0 & 1 & 0 & 32 \\
\hline 30 & 1 & 1 & 0 & 0 & 28 \\
\hline 31 & 1 & 0 & 1 & 1 & 33 \\
\hline 32 & 1 & 1 & 0 & 1 & 27 \\
\hline 33 & 0 & 0 & 0 & 0 & 2 \\
\hline 34 & 0 & 0 & 1 & 0 & 39 \\
\hline 35 & 0 & 1 & 0 & 0 & 26 \\
\hline 36 & 0 & 1 & 0 & 0 & 33 \\
\hline 37 & 0 & 1 & 0 & 0 & 32 \\
\hline 38 & 1 & 1 & 0 & 0 & 36 \\
\hline 39 & 1 & 1 & 0 & 1 & 25 \\
\hline 40 & 0 & 0 & 1 & 0 & 25 \\
\hline 41 & 0 & 0 & 0 & 0 & 34 \\
\hline 42 & 0 & 1 & 0 & 0 & 33 \\
\hline & & & &
\end{tabular}




\begin{tabular}{llllll}
\hline No & $\mathbf{Y}$ & $\mathbf{X}_{\mathbf{1}}$ & $\mathbf{X}_{\mathbf{2}}$ & $\mathbf{X}_{\mathbf{3}}$ & $\mathbf{X}_{\mathbf{4}}$ \\
\hline 43 & 1 & 1 & 0 & 0 & 24 \\
\hline 44 & 1 & 1 & 0 & 1 & 33 \\
\hline 45 & 1 & 1 & 0 & 0 & 25 \\
\hline 46 & 0 & 0 & 1 & 0 & 3 \\
\hline 47 & 0 & 0 & 0 & 0 & 37 \\
\hline 48 & 0 & 1 & 0 & 0 & 38 \\
\hline 49 & 1 & 1 & 0 & 0 & 31 \\
\hline
\end{tabular}

\begin{tabular}{llllll}
\hline No & $\mathbf{Y}$ & $\mathbf{X}_{\mathbf{1}}$ & $\mathbf{X}_{\mathbf{2}}$ & $\mathbf{X}_{\mathbf{3}}$ & $\mathbf{X}_{\mathbf{4}}$ \\
\hline 50 & 1 & 0 & 1 & 1 & 29 \\
\hline 51 & 1 & 1 & 0 & 0 & 38 \\
\hline 52 & 1 & 0 & 0 & 1 & 28 \\
\hline 53 & 1 & 1 & 0 & 1 & 27 \\
\hline 54 & 1 & 0 & 1 & 0 & 24 \\
\hline 55 & 1 & 0 & 1 & 0 & 35 \\
\hline
\end{tabular}

Keterangan:

$\mathrm{Y}=$ Status kejadian stillbirth

$X_{1}=$ Infeksi selama kehamilan $(0=$ tidak terjadinya infeksi kehamilan, $1=$ terjadinya infeksi kehamilan $)$

$X_{2}=$ Kelainan atau cacat bawaan $(0=$ tidak mengalami kelainan atau cacat bawaan, $1=$ mengalami kelainan atau cacat bawaan)

$X_{3}=$ Kondisi Ibu $(0=$ preklamsia, $1=$ diabetes $)$

$X_{4}=$ Usia Ibu $(0=24-31$ tahun, $1=32-40$ tahun $)$

Hasil analisis secara deskriptif menunjukkan bahwa dari 55 sampel ibu hamil terdapat 54,55\% atau 30 ibu yang mengalami stillbirth dan $45,45 \%$ atau 25 ibu yang tidak mengalami stillbirth. Selanjutnya dari 55 sampel tersebut persentase ibu yang mengalami infeksi kehamilan yaitu 54,55\% atau sebanyak 30 orang dan ibu yang tidak mengalami infeksi kehamilan yaitu $45,45 \%$ atau sebanyak 25 orang. Jika ditinjau dari faktor kelainan atau cacat bawaan, terdapat 18 ibu atau 32,73\% yang mengalami kelainan atau cacat bawaan dan 37 ibu atau $67,27 \%$ yang tidak mengalami kelainan atau cacat bawaan. Jika ditinjau dari riwayat penyakit yang diderita oleh ibu hamil, terdapat $41 \mathrm{ibu}$ atau $74,55 \%$ yang memiliki riwayat penyakit preklamsia atau darah tinggi dan 14 ibu atau $25,45 \%$ yang memiliki riwayat diabetes. Sedangkan jika ditinjau dari usia ibu hamil, terdapat $28 \mathrm{ibu}$ atau 50,91\% yang berusia 24 hingga 31 tahun mengalami stillbirth dan $27 \mathrm{ibu}$ atau 49,09\% yang berusia 31 tahun hingga 40 tahun mengalami stillbirth.

Berdasarkan model regresi logistik terdapat lima tahapan analisis yang dilakukan. Pertama pemilihan kandidat model dari setiap variabel prediktor. Hasil analisis untuk tahap pertama menunjukkan bahwa infeksi kehamilan, riwayat penyakit ibu, dan usia ibu mempengaruhi kejadian stillbirth. Kemudian untuk faktor kelainan atau cacat bawaan tidak berpengaruh secara signifikan. Selanjutnya dilakukan uji signifikan secara serentak dan terpisah dari dua variabel prediktor dengan melihat nilai $\mathrm{P}$ value, apabila $\mathrm{P}<0,05$ maka dapat disimpulkan berpengaruh terhadap kejadian Stillbirth (Tabel 4).

Tabel 4. Uji signifikan secara serentak dan terpisah

\begin{tabular}{llll}
\hline No & Variabel & Uji signifikan secara bersama & Uji signifikan secara terpisah \\
\hline 1 & $\mathrm{X}_{1}$ dan $\mathrm{X}_{2}$ & $\mathrm{P}=0,013$ (Berpengaruh) & $\begin{array}{l}\mathrm{X}_{1}=0,022 \text { ( Berpengaruh) } \\
\mathrm{X}_{2}=0,184 \text { ( Tidak berpengaruh) }\end{array}$ \\
\hline 2 & $\mathrm{X}_{1}$ dan $\mathrm{X}_{3}$ & $\mathrm{P}=0,003$ (Berpengaruh) & $\begin{array}{l}\mathrm{X}_{1}=0,057 \text { ( Tidak berpengaruh) } \\
\mathrm{X}_{3}=0,037 \text { (Berpengaruh) }\end{array}$ \\
\hline 3 & $\mathrm{X}_{1}$ dan $\mathrm{X}_{4}$ & $\mathrm{P}=0,010$ (Berpengaruh) & $\begin{array}{l}\mathrm{X}_{1}=0,028 \text { ( Berpengaruh) } \\
\mathrm{X}_{4}=0,104 \text { (Tidak berpengaruh) }\end{array}$ \\
\hline 4 & $\mathrm{X}_{2}$ dan $\mathrm{X}_{3}$ & $\mathrm{P}=0,016$ (Berpengaruh) & $\begin{array}{l}\mathrm{X}_{2}=0,648 \text { (Tidak berpengaruh) } \\
\mathrm{X}_{3}=0,019 \text { (Berpengaruh) }\end{array}$ \\
\hline 5 & $\mathrm{X}_{2}$ dan $\mathrm{X}_{4}$ & $\mathrm{P}=0,107$ (Tidak berpengaruh) & $\begin{array}{l}\mathrm{X}_{2}=0,555 \text { (Tidak berpengaruh) } \\
\mathrm{X}_{4}=0,070 \text { (Tidak Berpengaruh) }\end{array}$ \\
\hline 6 & $\mathrm{X}_{3}$ dan $\mathrm{X}_{4}$ & $\mathrm{P}=0,006$ (Berpengaruh) & $\begin{array}{l}\mathrm{X}_{3}=0,027 \text { ( Berpengaruh) } \\
\mathrm{X}_{4}=0,137 \text { (Tidak berpengaruh) }\end{array}$ \\
\hline
\end{tabular}

Tahapan berikutnya yaitu uji kecocokan model dari dua variable prediktor dengan melihat $\mathrm{P}$ value, apabila $\mathrm{P}>0,05$ maka model yang dibentuk sesuai atau cocok dengan nilai observasinya, seperti pada Tabel 5. 
Tabel 5. Uji kecocokan model

\begin{tabular}{lccc}
\hline No & Variabel & Uji Hosmer and Lemeshow Test & Keterangan \\
\hline 1 & $\mathrm{X}_{1}$ dan $\mathrm{X}_{2}$ & $\mathrm{P}=1,000$ & Model sesuai \\
\hline 2 & $\mathrm{X}_{1}$ dan $\mathrm{X}_{3}$ & $\mathrm{P}=0,353$ & Model sesuai \\
\hline 3 & $\mathrm{X}_{1}$ dan $\mathrm{X}_{4}$ & $\mathrm{P}=0,543$ & Model sesuai \\
\hline 4 & $\mathrm{X}_{2}$ dan $\mathrm{X}_{3}$ & $\mathrm{P}=0,576$ & Model sesuai \\
\hline 5 & $\mathrm{X}_{3}$ dan $\mathrm{X}_{4}$ & $\mathrm{P}=0,989$ & Model sesuai \\
\hline
\end{tabular}

Kemudian penentuan model dengan dua variabel prediktor yang dapat dilihat pada Tabel 6, berikut:

Tabel 6. Nilai G melibatkan dua variabel prediktor

\begin{tabular}{cccc}
\hline No & Variabel & Model & Nilai G \\
\hline 1 & $\mathrm{X}_{1}$ dan $\mathrm{X}_{2}$ & $\hat{\pi}(x)=\frac{\exp \left(2,416-2,639 X_{1}-1,569 X_{2}\right)}{1+\exp \left(2,416-2,639 X_{1}-1,569 X_{2}\right)}$ & 67,124 \\
\hline 2 & $\mathrm{X}_{1}$ dan $\mathrm{X}_{3}$ & $\hat{\pi}(x)=\frac{\exp \left(2,124-1,155 X_{1}-1,768 X_{3}\right)}{1+\exp \left(2,124-1,155 X_{1}-1,768 X_{3}\right)}$ & 63,999 \\
\hline 3 & $\mathrm{X}_{1}$ dan $\mathrm{X}_{4}$ & $\hat{\pi}(x)=\frac{\exp \left(0,313-1,302 X_{1}+0,961 X_{4}\right)}{1+\exp \left(0,313-1,302 X_{1}+0,961 X_{4}\right)}$ & 66,637 \\
\hline 4 & $\mathrm{X}_{2} \operatorname{dan} \mathrm{X}_{3}$ & $\hat{\pi}(x)=\frac{\exp \left(1,553+0,283 X_{2}-1,9723\right)}{1+\exp \left(1,553+0,283 X_{2}-1,972 X_{3}\right)}$ & 67,501 \\
\hline 5 & $\mathrm{X}_{3}$ dan $\mathrm{X}_{4}$ & $\hat{\pi}(x)=\frac{\exp \left(1,217-1,862 X_{3}+0,888 X_{4}\right)}{1+\exp \left(1,217-1,862 X_{3}+0,888 X_{4}\right)}$ & 65,472 \\
\hline
\end{tabular}

Hasil analisis berdasarkan Tabel 6 menunjukkan bahwa model terbaik regresi logistik biner yang melibatkan dua variabel prediktor (infeksi kehamilan dan kondisi kesehatan ibu) adalah

$$
\hat{\pi}(x)=\frac{\exp \left(2,124-1,155 X_{1}-1,768 X_{3}\right)}{1+\exp \left(2,124-1,155 X_{1}-1,768 X_{3}\right)}
$$

Kemudian dilanjutkan dengan penentuan model yang melibatkan tiga variabel prediktor. Uji signifikan secara serentak dan terpisah dari tiga variabel prediktor dapat dilihat pada Tabel 7.

Tabel 7. Uji signifikan secara serentak dan terpisah

\begin{tabular}{llll}
\hline No & Variabel & Uji signifikan secara serentak & Uji signifikan secara terpisah \\
\hline 1 & $\mathrm{X}_{1}, \mathrm{X}_{2}$ dan $\mathrm{X}_{3}$ & $\mathrm{P}=0,002$ (Berpengaruh) & $\mathrm{X}_{1}=0,036$ ( Berpengaruh) \\
& & $\mathrm{X}_{2}=0,149$ ( Tidak berpengaruh) \\
& & $\mathrm{X}_{3}=0,034$ ( Berpengaruh) \\
\hline 2 & $\mathrm{X}_{1}, \mathrm{X}_{2}$ dan $\mathrm{X}_{4}$ & $\mathrm{P}=0,006$ (Berpengaruh) & $\mathrm{X}_{1}=0,019$ ( Berpengaruh) \\
& & $\mathrm{X}_{2}=0,112$ ( Tidak berpengaruh) \\
& & $\mathrm{X}_{4}=0,060$ ( Tidak berpengaruh) \\
\hline 3 & $\mathrm{X}_{1}, \mathrm{X}_{3}$ dan $\mathrm{X}_{4}$ & $\mathrm{P}=0,004$ (Berpengaruh) & $\mathrm{X}_{1}=0,082$ ( Tidak berpengaruh) \\
& & & $\mathrm{X}_{3}=0,059$ ( Tidak berpengaruh) \\
& & $\mathrm{X}_{4}=0,208$ ( Tidak berpengaruh) \\
\hline 4 & $\mathrm{X}_{2}, \mathrm{X}_{3}$ dan $\mathrm{X}_{4}$ & $\mathrm{P}=0,016($ Berpengaruh) & $\mathrm{X}_{2}=0,872$ ( Tidak berpengaruh) \\
& & & $\mathrm{X}_{3}=0,030$ ( Berpengaruh) \\
& & $\mathrm{X}_{4}=0,154$ ( Tidak berpengaruh) \\
\hline
\end{tabular}

Selanjutnya yaitu uji kecocokan model dari tiga variabel prediktor dengan melihat nilai $\mathrm{P}$ value $>0,05$ dan dapat disimpulkan bahwa model yang dibentuk sesuai atau cocok dengan nilai observasinya (Tabel 8).

Tabel 8. Uji kecocokan model

\begin{tabular}{llcl}
\hline No & Variabel & Uji Hosmer and Lemeshow Test & Keterangan \\
\hline 1 & $\mathrm{X}_{1}, \mathrm{X}_{2}$ dan $\mathrm{X}_{3}$ & $\mathrm{P}=0,458$ & Model sesuai \\
\hline 2 & $\mathrm{X}_{1}, \mathrm{X}_{2}$ dan $\mathrm{X}_{4}$ & $\mathrm{P}=0,808$ & Model sesuai \\
\hline 3 & $\mathrm{X}_{2}, \mathrm{X}_{3}$ dan $\mathrm{X}_{4}$ & $\mathrm{P}=0,963$ & Model sesuai \\
\hline
\end{tabular}


Berdasarkan Tabel 8, terlihat bahwa model yang dibentuk sesuai atau cocok dengan nilai observasinya. Sedangkan untuk $\mathrm{X}_{1}, \mathrm{X}_{3}$ dan $\mathrm{X}_{4}$ berdasarkan hasil uji siginifikasin secara terpisah model tidak sesuai karena dari ketiga variabel prediktor tidak berpengaruh terhadap variabel respon.

Tahapan selanjutnya penentuan model dengan tiga variabel prediktor yang dapat dilihat pada Tabel 9 , berikut:

Tabel 9. Nilai G melibatkan Tiga variabel prediktor

\begin{tabular}{lccc}
\hline No & Variabel & Model & Nilai G \\
\hline 1 & $\mathrm{X}_{1}, \mathrm{X}_{2}$ dan $\mathrm{X} 3$ & $\hat{\pi}(x)=\frac{\exp \left(4,064-2,566 X_{1}-1,821 X_{2}-1,913 X_{3}\right)}{1+\exp \left(4,064-2,566 X_{1}-1,821 X_{2}-1,913 X_{3}\right)}$ & 61,362 \\
\hline 2 & $\mathrm{X}_{1}, \mathrm{X}_{2}$ dan $\mathrm{X}_{4}$ & $\hat{\pi}(x)=\frac{\exp \left(2,162-2,787 X_{1}-1,960 X_{2}+1,182 X_{4}\right)}{1+\exp \left(2,162-2,787 X_{1}-1,960 X_{2}+1,182 X_{4}\right)}$ & 63,428 \\
\hline 3 & $\mathrm{X}_{2}, \mathrm{X}_{3}$ dan $\mathrm{X}_{4}$ & $\hat{\pi}(x)=\frac{\exp \left(1,553+0,283 X_{2}-1,9723\right)}{1+\exp \left(1,553+0,283 X_{2}-1,972 X_{3}\right)}$ & 65,447 \\
\hline
\end{tabular}

Hasil analisis tahap ketiga menunjukkan bahwa model terbaik regresi logistik biner yang melibatkan tiga variabel prediktor adalah:

$$
\hat{\pi}(x)=\frac{\exp \left(4,064-2,566 X_{1}-1,821 X_{2}-1,913 X_{3}\right)}{1+\exp \left(4,064-2,566 X_{1}-1,821 X_{2}-1,913 X_{3}\right)}
$$

Keempat penentuan model dengan empat variabel prediktor. Kemudian dengan cara yang sama juga dilakukan Uji signifikan secara serentak dan terpisah yang melibatkan empat variabel pada Tabel 10.

Tabel 10. Uji signifikan secara serentak dan terpisah

\begin{tabular}{clrl}
\hline No & Variabel & Uji signifikan secara serentak & Uji signifikan secara terpisah \\
\hline 1 & $\mathrm{X}_{1}, \mathrm{X}_{2}, \mathrm{X}_{3}$, & $\mathrm{P}=0,002$ (Berpengaruh) & $\mathrm{X}_{1}=0,031$ ( Berpengaruh) \\
& dan $\mathrm{X}_{4}$ & & $\mathrm{X}_{2}=0,100$ ( Tidak berpengaruh) \\
& & $\mathrm{X}_{3}=0,054$ ( Tidak berpengaruh) \\
& & $\mathrm{X}_{4}=0,121$ (Tidak berpengaruh) \\
\hline
\end{tabular}

Dari hasil uji kecocokan model untuk yang melibatkan empat variabel menunjukkan bahwa model yang dibentuk sesuai dengan nilai $\mathrm{P}$ value $=0,898>0,05$. Hasil analisis menunjukkan bahwa model terbaik regresi logistik biner yang melibatkan empat variabel prediktor adalah $\hat{\pi}(x)=\frac{\exp \left(3,753+0,748 X_{1}-2,185 X_{2}-1,750 X_{3}+1,021 X_{4}\right)}{1+\exp \left(3,753+0,748 X_{1}-2,185 X_{2}-1,750 X_{3}+1,021 X_{4}\right)}$. Kelima pemilihan model terbaik dari model-model yang telah dibentuk.

Tabel 4. Model terbaik dari semua model yang terpilih

\begin{tabular}{lccc}
\hline No & Variabel & Model & Nilai G \\
\hline 1 & $\mathrm{X}_{1}$ dan $\mathrm{X}_{3}$ & $\hat{\pi}(x)=\frac{\exp \left(2,124-1,155 X_{1}-1,768 X_{3}\right)}{1+\exp \left(2,124-1,155 X_{1}-1,768 X_{3}\right)}$ & 63,999 \\
\hline 2 & $\mathrm{X}_{1}, \mathrm{X}_{2}$ dan $\mathrm{X}_{3}$ & $\hat{\pi}(x)=\frac{\exp \left(4,064-2,566 X_{1}-1,821 X_{2}-1,913 X_{3}\right)}{1+\exp \left(4,064-2,566 X_{1}-1,821 X_{2}-1,913 X_{3}\right)}$ & 61,362 \\
\hline 3 & $\mathrm{X}_{1}, \mathrm{X}_{2}, \mathrm{X}_{3}, \operatorname{dan} \mathrm{X}_{4}$ & $\hat{\pi}(x)=\frac{\exp \left(3,753+0,748 X_{1}-2,185 X_{2}-1,750 X_{3}+1,021 X_{4}\right)}{1+\exp \left(3,753+0,748 X_{1}-2,185 X_{2}-1,750 X_{3}+1,021 X_{4}\right)}$ & 58,891 \\
\hline
\end{tabular}

Hasil analisis tahap kelima menunjukkan bahwa model yang terpilih adalah:

$$
\hat{\pi}(x)=\frac{\exp \left(3,753+0,748 X_{1}-2,185 X_{2}-1,750 X_{3}+1,021 X_{4}\right)}{1+\exp \left(3,753+0,748 X_{1}-2,185 X_{2}-1,750 X_{3}+1,021 X_{4}\right)} .
$$

Berdasarkan model tersebut, diperoleh bahwa ibu yang mengalami infeksi kehamilan 2 kali lebih berpengaruh terhadap kejadian stillbirth dibandingkan dengan ibu yang tidak mengalami infeksi kehamilan. Sementara itu, untuk variabel kelainan atau cacat bawaan, kondisi kesehatan ibu dan usia ibu berpengaruh terhadap prediksi terjadinya stillbirth, namun pengaruhnya kecil dibandingkan dengan infeksi kehamilan. 


\section{KESIMPULAN}

Berdasarkan hasil pengolahan data, diperoleh kesimpulan kesimpulan, sebagai berikut:

1. Terdapat sebanyak 54,55\% dari jumlah keseluruhan ibu hamil di tiga kecamatan Kabupaten Aceh Timur mengalami stillbirth. Ibu yang mengalami stillbirth memiliki riwayat infeksi kehamilan sebanyak 21 orang, riwayat kelainan atau cacat bawaan sebanyak 8 orang, kondisi kesehatan ibu dengan riwayat preklamsia sebanyak 12 orang dan diabetes sebanyak 18 orang, dengan riwayat usia ibu antara 21 sampai 30 tahun sebnyak 16 orang dan usia ibu sampai 31 sampai 40 tahun sebanyak 14 orang.

2. Berdasarkan model regresi logistik biner diperoleh bahwa infeksi selama kehamilan yang paling mempengaruhi terjadinya stillbirth. Ibu yang mengalami infeksi kehamilan 2 kali lebih berpengaruh dibandingkan dengan ibu yang tidak mengalami infeksi kehamilan.

3. Model regresi logistik biner untuk menggambarkan hubungan antara stillbirth pada ibu hamil dengan infeksi kehamilan, cacat bawaan, kondisi kesehatan ibu, dan usia ibu adalah

$$
\hat{\pi}(x)=\frac{\exp \left(3,753+0,748 X_{1}-2,185 X_{2}-1,750 X_{3}+1,021 X_{4}\right)}{1+\exp \left(3,753+0,748 X_{1}-2,185 X_{2}-1,750 X_{3}+1,021 X_{4}\right)}
$$

\section{DAFTAR PUSTAKA}

[1] S. M. Putri and W. M. Ningrum, "Gambaran Penyebab Bayi Lahir Mati (Stillbirth) Pada Proses Persalinan,” Midwifery J. Galuh Univ., vol. 1, pp. 37-44, 2019.

[2] B. P. Statistika, “Angka Kematian Bayi,” Sumber : Sensus Penduduk 1971, 1980, 1990, SDKI 1994 dan 1997, 2015.

[3] Databoks, "Meski Menurun, Angka Kematian Bayi di Indonesia Masih Tinggi,” 2016. .

[4] R. Herliafifah, "Stillbirth (Bayi Lahir Mati)," 2020. .

[5] A. Mahardika and W. M. Ningrum, "Gambaran Faktor Risiko Pada Ibu Dengan Bayi Lahir Mati (Stillbirth) Di Kabupaten Tasikmalaya Tahun 2017," J. Midwifery Public Heal., vol. 1, no. 2, pp. 1-6, 2019, doi: 10.25157/jmph.v1i2.3027.

[6] L. Noralita, “Analisis Faktor Risiko Kejadian Lahir Mati di Kota Surakarta,” Universitas Muhammadiyah Surakarta, 2011.

[7] K. M. Kotimah and P. S. Wulandari, "Model Regresi Logistik Biner Stratifikasi Pada Partisipasi Ekonomi Perempuan Di Provinsi Jawa Timur," J. Sains dan Seni Pomits, vol. 3, no. 1, p. D-1-D-6, 2014.

[8] A. T. Basuki, "Regresi Logistik Biner," J. Pendidik. MIPA, 2018.

[9] A. Amelia, F. Mulyani, and U. Nabilla, "Analisis Faktor yang Mempengaruhi Status Penerimaan Beras Keluarga Miskin Menggunakan Regresi Logistik Biner di Kecamatan Langsa Barat,” Barekeng J. Ilmu Mat. dan Terap., vol. 14, no. 2, pp. 175186, 2020, doi: 10.30598/barekengvol14iss2pp181-192.

[10] S. Utomo, "Model Regresi Logistik Untuk Menunjukkan Pengaruh Pendapatan Per Kapita, Tingkat Pendidikan, dan Status Pekerjaan Terhadap Status Gizi Masyarakat Kota Surakarta," 2009.

[11] D. G. Kleinbaum and M. Klein, Logistic Regression: A Self-Learning Text, Third Edition. New York: Springer, 2008.

[12] L. M. Nasution, "Statistik Deskriptif," Hikmah, vol. 14, no. 1, pp. 49-55, 2017.

[13] G. King and L. Zeng, "Logistic regression in rare events data,” J. Stat. Softw., 2003, doi: 10.18637/jss.v008.i02.

[14] D. Monica, D. Devianto, and F. Yanuar, "Pemodelan Faktor-Faktor yang Mempengaruhi Kejadian DBD (Demam Berdarah Dengue) Menggunakan Regresi Logistik Biner untuk Wilayah Regional 2 Indonesia (Sumatera)," J. Mat. UNAND, vol. 6, no. 1, pp. 9-16, 2017, doi: 10.25077/jmu.6.1.9-16.2017.

[15] D. W. and S. L. Hosmer, “Applied Logistic Regression, Second Edition.” John Wiley \& Sons, Inc, Canada, 2000

[16] S. Bersama et al., "Pemodelan Regresi Logistik Biner terhadap Peminat ITS di Seleksi Bersama Masuk Perguruan Tinggi Negeri (SBMPTN) 2014,” vol. 4, no. 1, pp. 115-120, 2015.

[17] A. Heryana, "Uji Chi-Square," Catatan Ade Heryana, 2017. http://adeheryana.weblog.esaunggul.ac.id/2017/06/04/uji-chisquare/.

[18] Daruyani Safitri, "Faktor-Faktor yang Mempengaruhi Indeks Prestasi Mahasiswa FSM Universitas Diponegoro Semester Pertama dengan Metode Regresi Logistik Biner,” 2013. 